The Horsemen of Israel 


\title{
HISTORY, ARCHAEOLOGY, AND CULTURE OF THE LEVANT
}

\author{
Edited by \\ JefFrey A. Blakely University of Wisconsin, Madison \\ K. Lawson Younger Trinity Evangelical Divinity School
}

1. The Horsemen of Israel: Horses and Chariotry in Monarchic Israel (Ninth-Eighth Centuries B.C.E.), by Deborah O'Daniel Cantrell

2. Donkeys in the Biblical World: Ceremony and Symbol, by Kenneth C. Way

3. The Wilderness Itineraries: Genre, Geography, and the Growth of Torah, by Angela R. Roskop 


\section{The Horsemen of Israel}

Horses and Chariotry in Monarchic Israel

(Ninth-Eighth Centuries B.C.E.)

Deborah O'Daniel Cantrell

Winona Lake, Indiana

EISENBRAUNS

2011 


\author{
(C) 2011 by Eisenbrauns Inc. \\ All rights reserved \\ Printed in the United States of America \\ www.eisenbrauns.com
}

\title{
Library of Congress Cataloging-in-Publication Data
}

Cantrell, Deborah O’Daniel.

The horsemen of Israel : horses and chariotry in monarchic Israel (ninth-eighth centuries B.C.E.) / by Deborah O’Daniel Cantrell.

p. $\quad \mathrm{cm} .-$ (History, archaeology, and culture of the Levant ; 1)

Includes bibliographical references and indexes.

ISBN 978-1-57506-204-4 (hardback : alk. paper)

1. Horses-Israel-History. 2. Chariots-Israel-History. 3. Iron age-Israel.

4. Military history, Ancient. 5. Military art and science-History-To 500. 6. Warfare,

Prehistoric-Israel. 7. Bible. O.T.-Criticism, interpretation, etc. 8. Israel-Antiquities.

I. Title.

SF285.I75C36 2011

$636.109334-\mathrm{dc} 23$

2011018405

The paper used in this publication meets the minimum requirements of the American National Standard for Information Sciences-Permanence of Paper for Printed Library Materials, ANSI Z39.48-1984. @ ${ }^{\mathrm{TM}}$ 


\section{In Memory of \\ Mr. and Mrs. Finis A. O'Daniel}

"Perseverance Pays." 
